\title{
A new species of Chrysocephalum (Asteraceae: Gnaphalieae) from New South Wales
}

\author{
Joy Everett
}

\begin{abstract}
Everett, Joy (National Herbarium of New South Wales, Royal Botanic Gardens, Mrs Macquaries Road, Sydney, NSW 2000, Australia). 1999. A new species of Chrysocephalum (Asteraceae: Gnaphalieae) from New South Wales. Telopea 8(3): 311-313. Chrysocephalum serpens, a new species from the coastal ranges of New South Wales, is similar to C. semicalvum but differs in having ovate leaves and a scrambling habit. It is restricted in distribution and its conservation status is considered to be 3RC-.
\end{abstract}

\section{Chrysocephalum serpens Everett, sp. nov.}

Chrysocephalo semicalvo similis sed foliis ovatis et habitu repenti differt.

Type: New South Wales: The Castles, Carrai State Forest, J. Everett 1013 \& D. Binns, 7 Dec 1987 (holo NSW 198261; iso BRI).

Prostrate to ascending scrambling herb to $15 \mathrm{~cm}$ high, rooting at the nodes, and forming a loose to dense mat. Young stems densely glandular and scaberulous, older stems reddish, glabrescent and ribbed. Leaves cauline, spathulate, obovate or oblong, attenuate at the base, margins flat or slightly inrolled, but tightly inrolled at the tip so appearing apiculate, 10-26(-40) $\mathrm{mm}$ long, 4-10 $\mathrm{mm}$ wide, with the midvein prominent and adaxially indented; blades abaxially glandular and hispid with multiseptate hairs with long, fine apices; adaxially glandular, sticky, and hispid with multiseptate hairs. Scape densely glandular 6.5-9 cm long. Compound heads 9-11 $\mathrm{mm}$ diameter with up to 100 florets, receptacle slightly conical. Involucral bracts in several series, the outer with cartilaginous claws, with membranous laminas, woolly-ciliate on the margins and abaxial surface. Florets bisexual and female, all florets apparently fertile, bisexual florets campanulate, a very few outer florets female and filiform. Corolla bright yellow. Anthers tailed. Style branches truncate. Achenes of bisexual florets oblong, golden brown with 4 paler longitudinal ribs, glabrous; those of female florets similar but with only 2 ribs; pappus of bisexual florets a ring of bristles, shortly fused and barbellate at the base, subplumose at the tip; pappus of female florets absent or of 1 or 2 free bristles. (Fig. 1).

Distribution: known only from three isolated sites in the New South Wales coastal ranges north of Taree.

Ecology: locally frequent, restricted to skeletal soils on outcrops of metamorphosed sedimentary rock along the coastal ranges. In open forest of Eucalyptus melliodora or E. microcarpa, E. propinqua and Lophostemon confertus, and with grassy understorey including Themeda australis and Lomandra longifolia.

Conservation status: $3 \mathrm{RC}$ - is recommended.

Epithet: from the Latin 'serpens' referring to the trailing, spreading habit.

Notes: Chrysocephalum serpens seems closely related to C. semicalvum (F. Muell.) Paul G. Wilson, with which it shares a similar capitulum and floret structure, but differs markedly in the ovate leaves and scrambling habit. Note that the receptacle of 


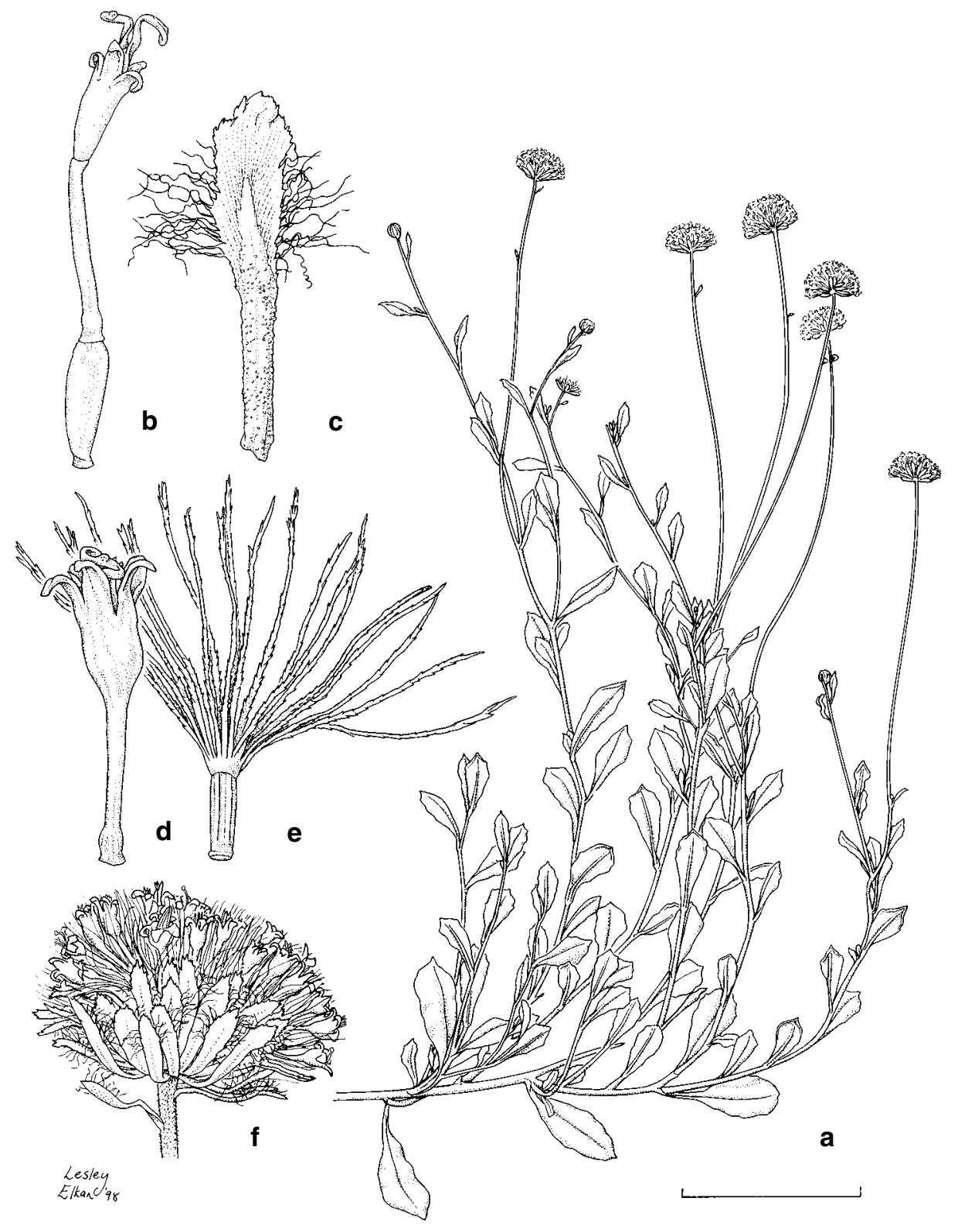

Fig. 1. Chrysocephalum serpens. a, habit; $\mathbf{b}$, outer female floret; $\mathbf{c}$, intermediate involucral bract; d, inner bisexual floral tube; e, achene of inner bisexual floret; $\mathbf{f}$, capitulum. (a, c-f from Everett 1013 \& Binns, b from Benwell NSW430018 ). Scale bar: $\mathrm{a}=3.6 \mathrm{~cm}, \mathrm{~b}-\mathrm{e}=2 \mathrm{~mm}, \mathrm{f}=6 \mathrm{~mm}$. 
Chrysocephalum is described by Everett (1992) as flat, but both C. semicalvum and C. serpens have slightly conical receptacles. Vegetatively $C$. serpens closely resembles Ozothamnus bidwillii (Benth.) Anderberg, in the leaf-shape and trailing habit, and could easily be misidentified if flowering material were not available, although $O$. bidwillii grows in quite different habitats, in dry rainforest or rainforest margins.

C. serpens has been in cultivation at the Royal Botanic Gardens, Sydney for 12 years (from cuttings collected at the type locality) and makes an interesting, enduring ground cover.

Specimens examined: New South Wales: North Coast: Bluff Mountain, Mt Marsh State Forest, Benwell s.n., Mar 1998 (NSW 430018); The Castles Flora Reserve, Carrai State Forest, Binns DLB139, Apr 1987 (NSW).

\section{Acknowledgments}

Thanks to Lesley Elkan for the illustration, and to Doug Binns for taking me to the Carrai State Forest collecting site. Peter Wilson is thanked for assistance with the Latin diagnosis.

\section{Reference}

Everett, J. (1992) Chrysocephalum. Pp. 233-235 in Harden, G.J. (ed.), Flora of New South Wales, vol. 3. (New South Wales University Press: Kensington).

Manuscript received 23 July 1999 Manuscript accepted 21 September 1999 
